\title{
The Impact of the U.S. Election on China and America
}

\author{
Guanghui Wu
}

\author{
Wuhan University \\ *Corresponding author. Email: chriswu1022@163.com
}

\begin{abstract}
In the context of the US general election, the election results will have a great impact on the economy, politics, culture and environment of the United States and the world. In view of the problems of the American general election, this paper studies the impact of the different results of the US general election on the United States and China, and establishes the impact model of the American general election.

Analyzing the impact of the election results on the United States, this paper first analyzes the economic conditions of the presidents of the United States during their political periods. It is found that the economic conditions of the Democratic Party and the Republican Party are very different during the ruling period. Therefore, this paper assumes that the influence of the president on the United States is largely determined by the political party to which he belongs. Furthermore, this paper analyzes the debt, GDP, employment and unemployment rate of different election results in time series, and concludes the specific impact of different election results on the economy. In addition, considering the different attitudes of trump and Biden on the new crown epidemic, this paper also established a SEIR model based on biology to simulate the epidemic development in the United States under different election results.

Analyzing the impact of the U.S. election results on China, this paper first considers the impact of the US Democratic Party and Republican Party on China's economy, and then takes into account the foreign trade policy positions of trump and Biden, establishes the trade gravity model and grey prediction model to predict and analyze China inflation, trade, foreign investment, etc. and finally obtains the US election conclusion: The specific impact of the results on China economy.

Based on the above results, this paper makes relevant analysis and suggestions from three dimensions of China domestic development, China and the United States, and China and the world. Finally, the paper puts forward some reasonable suggestions, such as mobilizing domestic dual circulation, alerting Sino US relations and integrating into the world economy.
\end{abstract}

Keywords: time series, SEIR model, trade gravity model, grey forecast

\section{RESTATEMENT}

The US presidential election is held every four years. 2020 is the year of US presidential election, with Republican candidate Donald Trump and Democratic counterpart Joe Biden running for president. The candidates of both parties have different political stands and administrative programs in finance and trade, economic and financial governance, and some other different key development areas (such as COVID-19 fighting measures, infrastructure, taxation, environmental protection, medical insurance, employment, trade, immigration, education, etc.). The election of different candidates will shape different strategic patterns of global economic and financial development, and have a greater impact on the U.S. economy and the global economy (including China's economy). How will different policies affect America's economy and China's economy? How should China respond? In the following analysis, this article will collect the candidate's policy propositions, policy guidelines and relevant data in different fields, and answer the following questions:

1. Establish a mathematical model and use relevant data to quantitatively analyze the possible impact of different candidates elected on the U.S. economy.

2. Establish a mathematical model and use relevant data to quantitatively analyze the possible impact of different candidates elected on China's economy.

3. Combined with the mathematical models of questions 1 and 2, what suggestions would be made to 
China's economic countermeasures and policies in related areas in both cases (which party wins)?

\section{PROBLEM ANALYSIS}

In view of the first question, analyzing the impact of the election results on the United States, this paper first analyzes the economic conditions of the presidents of the United States during their political periods. It is found that the economic conditions of the Democratic Party and the Republican Party are very different during the ruling period. Therefore, this paper assumes that the influence of the president on the United States is largely determined by the political party to which he belongs. Furthermore, this paper analyzes the debt, GDP, employment and unemployment rate of different election results in time series, and concludes the specific impact of different election results on the economy.

In addition, considering the different attitudes of trump and Biden on the new coronation epidemic, this paper also established a SIR model based on biology to simulate the epidemic development in the United States under different election results.[2]

In view of the second question, analyzing the impact of the U.S. election results on China, this paper first considers the impact of the US Democratic Party and Republican Party on China economy, and then takes into account the foreign trade policy positions of trump and Biden, establishes the trade gravity model and grey prediction model to predict and analyze China inflation, trade, foreign investment, etc., and finally obtains the US election conclusion: The specific impact of the results on China economy. [1]

\section{PROBLEM ASSUMPTION}

1. Suppose that the influence of the president of the United States on the United States mainly depends on his political party.

2. Suppose that the influence of the US president on China mainly depends on his political party.

3. It is assumed that the data taken is true, accurate and effective.

4. It is assumed that the development simulation of the U.S. epidemic does not consider the large-scale use of effective vaccines.

5. It is assumed that the trade between China and the United States is mainly influenced by the two countries, while the influence of other countries is ignored.

\section{SYMBOL MEANING}

\begin{tabular}{cc}
\hline Symbol & Symbol Meaning \\
$\mathrm{I}$ & Infected \\
$\mathrm{R}$ & susceptible \\
$\omega_{j i}$ & remover \\
$\mathrm{ACF}$ & Weight \\
$\mathrm{PACF}$ & Autocorrelation coefficient \\
$\beta_{p}$ & Partial autocorrelation \\
$\alpha_{q}$ & coefficient \\
\hline
\end{tabular}

\section{U.S. ELECTION IMPACT MODEL}

\subsection{Data collection and analysis}

In the context of the US general election, the election results will have a great impact on the economy, politics, culture and environment of the United States and the world. In view of the problems of the American general election, this paper studies the impact of the different results of the US general election on the United States and China, and establishes the impact model of the American general election.

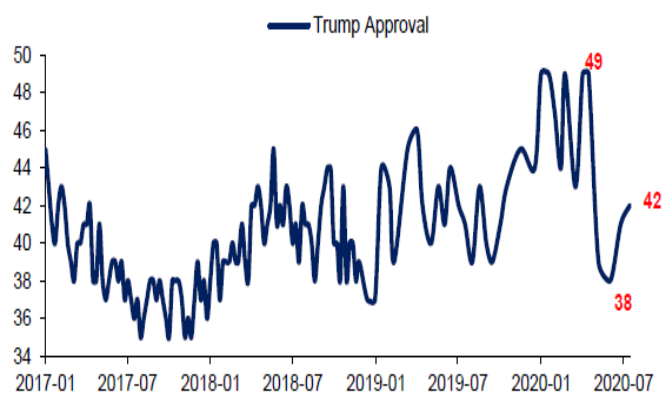

Figure 1 Changes in Trump's approval rating

With the changing support rate of current president trump of the United States, whether he can be reelected is uncertain. In addition, there are still many swing states in the current election states. 


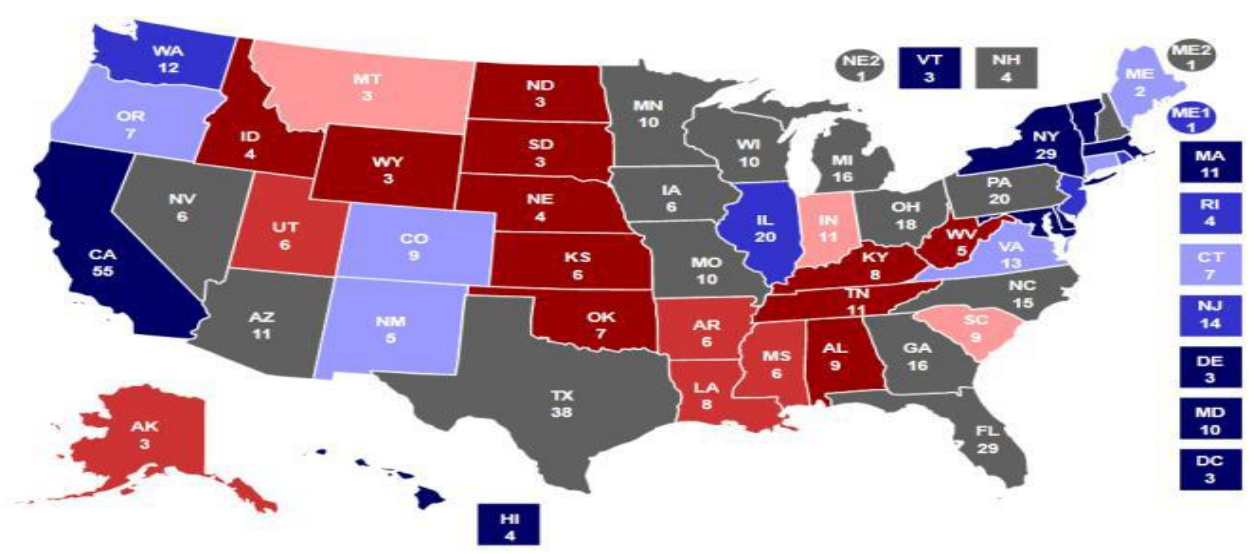

Figure 2 The state of support for elections

Therefore, the next president is still unknown. This paper analyzes the impact of Biden election or Trump election on the United States and China.

\subsection{Analysis of the impact of US election results on the United States}

In view of the impact of the election results on the United States, this paper first analyzes the economic situation of the presidents of the United States during their political periods. It is found that the economic conditions of the Democratic Party and the Republican Party are very different during the ruling period. Therefore, this paper assumes that the influence of the president on the United States is largely determined by the political party to which he belongs. [3]

As shown in the figure below, the U.S. economy during the various presidents of the United States.

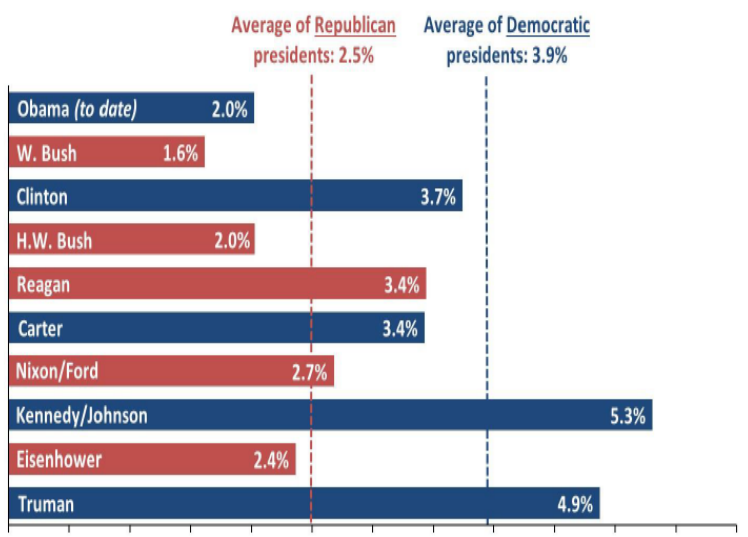

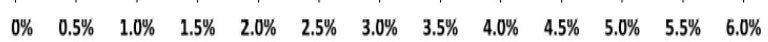

Figure 3 Average annualized growth rate of real GDP

The data show that, since World War II, the economy has performed substantially better under Democratic presidents. On average, real (inflation-adjusted) GDP has grown about 1.6 times faster under Democrats than under Republicans. While the strong performance under Presidents Truman, Kennedy and Johnson certainly contributes to this gap, the starting point does not matter: GDP has grown faster under Democrats regardless of whether the analysis begins with President Truman, President Kennedy or President Reagan.[4]

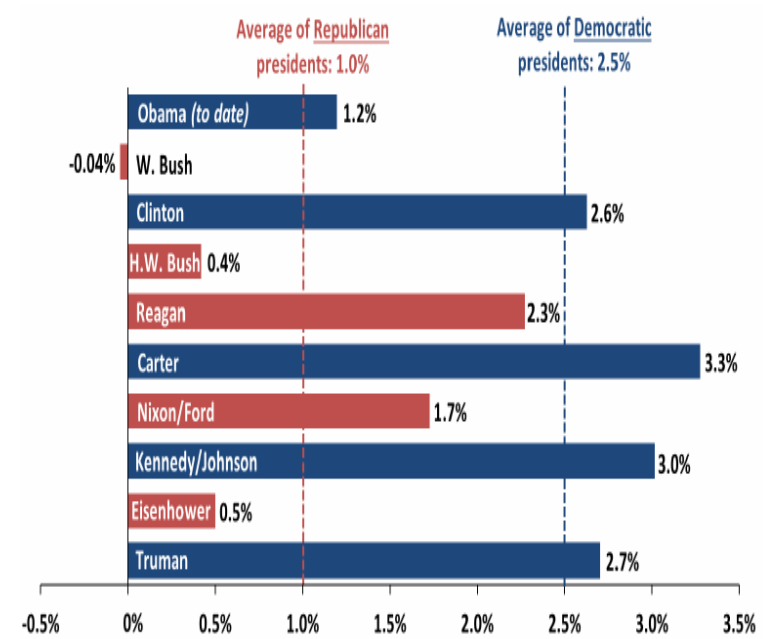

Figure 4 Average annualized growth of private-secotor payrolls

The findings for private-sector job growth are even more striking: businesses have added jobs at a nearly 2.5 times faster rate under Democrats than under Republicans, on average. In fact, the private-sector job growth gap between Democrats and Republicans is even greater than the gap when including government jobs.

Therefore, this paper assumes that the influence of the president on the United States is largely determined by the political party he belongs to. The following table shows the different views of trump and Biden in different aspects.[5] 
Table 1 Biden and Trump's positions in different aspects

\begin{tabular}{|c|c|c|}
\hline Individual Taxes & Biden & Trump \\
\hline Individual Rate & $\begin{array}{l}\text { Increase the top rate from } 37 \% \text { to } 39.6 \% \text { (including Affordable } \\
\text { Care Act tax of } 3.8 \% \text { ) }\end{array}$ & $\begin{array}{l}\text { Make permanent individual tax cuts included in the TCIA } \\
\text { including the } 37 \% \text { top rate } \\
\text { Proposed an unspecified tax cut to boost take-home pay }\end{array}$ \\
\hline Deductions & $\begin{array}{l}\text { Cap itemized deductions above the } 28 \% \text { rate } \\
\text { Reinstate Pease Limitation lowering itemized deductions by } 3 \% \\
\text { on income }>\$ 400 k\end{array}$ & $\begin{array}{l}\text { Make permanent the changes included in the TCJA including } \\
\text { the increase in standard deduction and child tax credits }\end{array}$ \\
\hline $\begin{array}{l}\text { Small Business } \\
\text { Income }\end{array}$ & $\begin{array}{l}\text { Phase-out the } 20 \% \text { deduction of qualified business income on } \\
\text { incomes }>\$ 400 k\end{array}$ & Make permanent the $20 \%$ tax rate reduction \\
\hline Capital Gains & Treat capital gains as ordinary income on incomes $>\$ 1 \mathrm{~m}$ & $\begin{array}{l}\text { Possibly reduce from } 20 \% \text { to } 15 \% \text { (unclear whether inclusive of } \\
\text { Net Investment Income Tax) }\end{array}$ \\
\hline Estate Taxes & $\begin{array}{l}\text { Disallow steps-up in basis on estates } \\
\text { Reinstate pre-2018 exemptions on estates less than } \$ 11.6 \mathrm{~m} \\
\text { and } \$ 23.2 \mathrm{~m} \text { for individuals and couples, respectively }\end{array}$ & Maintain the step-up in asset value and make it permanent \\
\hline $\begin{array}{l}\text { Social Security } \\
\text { Tax }\end{array}$ & Impose the $12.4 \%$ social security tax on incomes $>\$ 400 k$ & $\begin{array}{l}\text { Maintain current law: Social Security tax not collected on } \\
\text { income }>\$ 138 \mathrm{k}\end{array}$ \\
\hline $\begin{array}{l}\text { Retirement } \\
\text { Savings } \\
\text { Incentives }\end{array}$ & Increase incentives to save in a retirement plan & Create a universal, tax-free savings account \\
\hline
\end{tabular}

From the above table, we can see that there are great differences in individual rate, education, estate taxes and so on. In view of these differences, this paper establishes an implementation sequence model to analyze the situation after he was elected president. The specific model is as follows.

- $\quad$ Autoregressive model (AR):

If the time series meets:

$$
y_{t}=\beta_{1} y_{t-1}+\beta_{2} y_{t-2}+\cdots+\beta_{p} y_{t-p}+\varepsilon_{t}
$$

Among them is a sequence of independent and identically distributed random variables, and satisfies:

$$
\operatorname{Var} \varepsilon_{t}=\sigma_{\varepsilon}^{2}>0, \quad E\left(\varepsilon_{t}\right)=0
$$

- $\quad$ Moving Average Model (MA):

If the time series meets:

$$
y_{t}=\varepsilon_{t}+\alpha_{1} \varepsilon_{t-1}+\alpha_{2} \varepsilon_{t-2}+\cdots++\alpha_{q} \varepsilon_{t-q}
$$

The time series is said to obey the q-order moving average model; the stable condition of the moving average model: stable under any conditions.

(ARMA)

$$
\text { Autoregressive Moving Average Model }
$$

If the time series meets:

$$
\left\{\begin{array}{l}
y_{t}=\beta_{1} y_{t-1}+\beta_{2} y_{t-2}+\cdots+\beta_{p} y_{t-p}+\varepsilon_{t}+\alpha_{1} \varepsilon_{t-1}+\alpha_{2} \varepsilon_{t-2}+\cdots++\alpha_{q} \varepsilon_{t-q} \\
\beta_{p} \neq 0, \alpha_{q} \\
E\left(\varepsilon_{t}\right)=0, \operatorname{Var}\left(\varepsilon_{t}\right)=\sigma_{\varepsilon}^{2}, E\left(\varepsilon_{t} \varepsilon_{s}\right)=0, s \neq t \\
E\left(y_{s} \varepsilon_{t}\right)=0, \forall s<t
\end{array}\right.
$$

model (ARIMA)

What we discussed before are all stationary time series, but the time series may be a unit root process of order $\mathrm{d}$. For this reason, we need to differentiate the data and convert it into a stationary time series before modeling. For the ARIMA(p,d,q) model:

$$
y_{t}^{\prime}=\alpha_{0}+\sum_{i=1}^{p} \alpha_{i} y_{t-i}^{\prime}+\varepsilon_{t}+\sum_{i=1}^{q} \beta_{i} \varepsilon_{t-i}
$$

- ARIMA parameter estimation

Carry out ACF and PACF inspection on it:
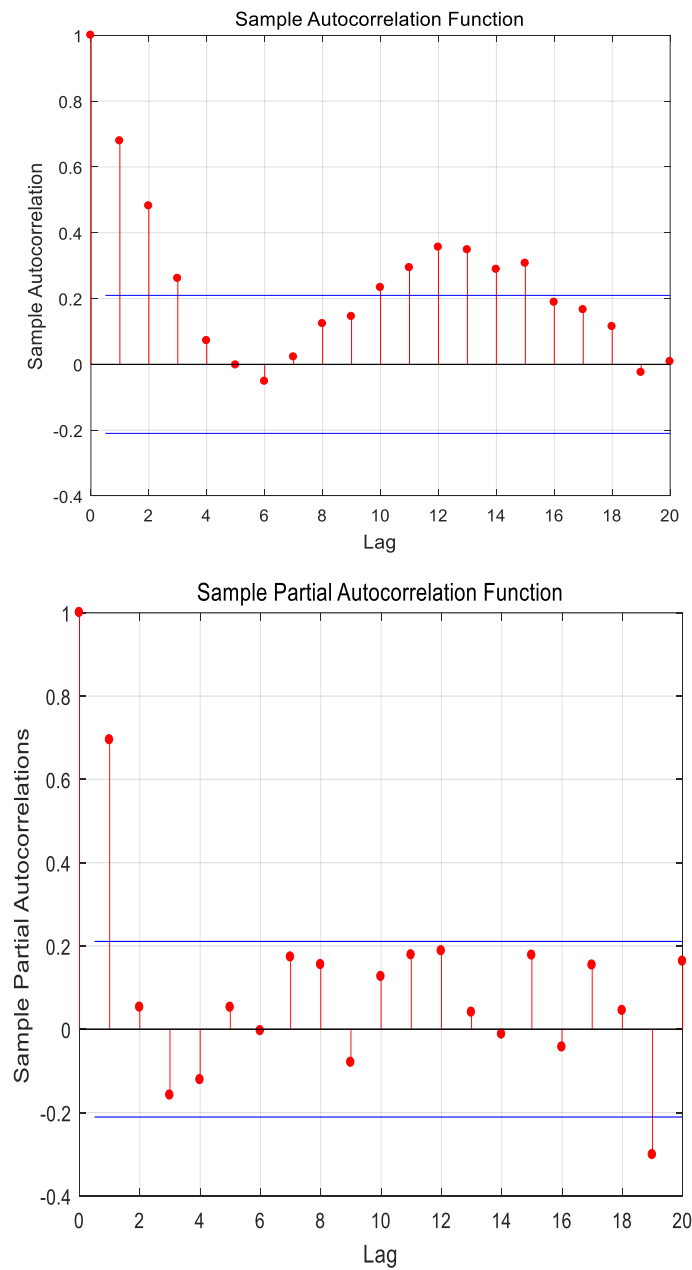

Figure $5 \mathrm{ACF}$ and PACF test pattern

According to the ACF and PACF tests, the parameters of the ARIMA model can be adjusted to 2,1,3. That is, the $\operatorname{ARIMA}(2,1,3)$ model is used in this article.

The result is as follows: 


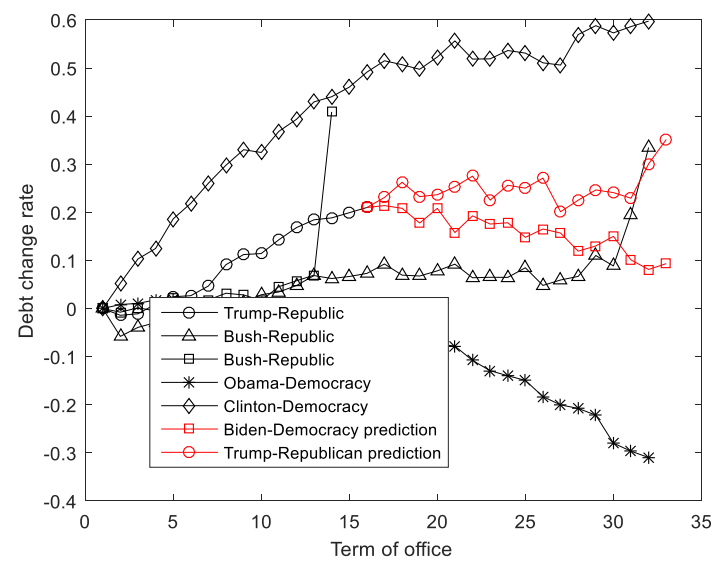

Figure 6 Changes in US debt under different US presidents

When trump took office, total debt accounted for about $76 \%$ of GDP. But by mid-2020, it will be 105 percent, up 29 percent during his presidency. Economists often advocate paying down debt when the economy is strong and spending more when the economy is weak. Although trump has promised to "get rid of" debt, it has expanded it. While much of the increase came from coronavirus relief funds, early policies such as corporate tax cuts and increased defense spending also contributed to the growth. As can be seen from the forecast in the figure, if Biden is elected, the debt will be reduced to a certain extent, while trump will increase the debt. [6]

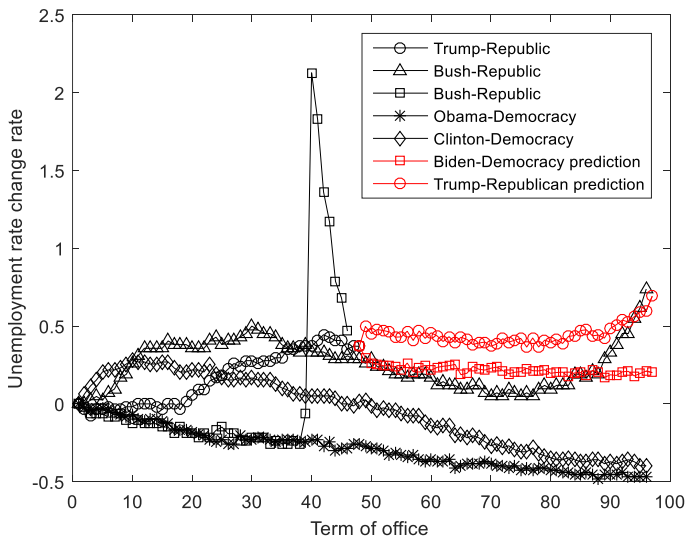

Figure 7 Changes in US unemployment under different US presidents

When trump took office, he inherited from Obama one of the most powerful job markets in American history. But covid-19 quickly ended that. The unemployment rate soared to $14.7 \%$, up 10 percentage points when Mr. trump took office. Despite improvements since then, the unemployment rate remained high in September. No other president has seen such a sudden surge in unemployment. As can be seen from the forecast in the figure, if Biden is elected, the unemployment rate will be reduced to a certain extent, while trump will increase the unemployment rate.

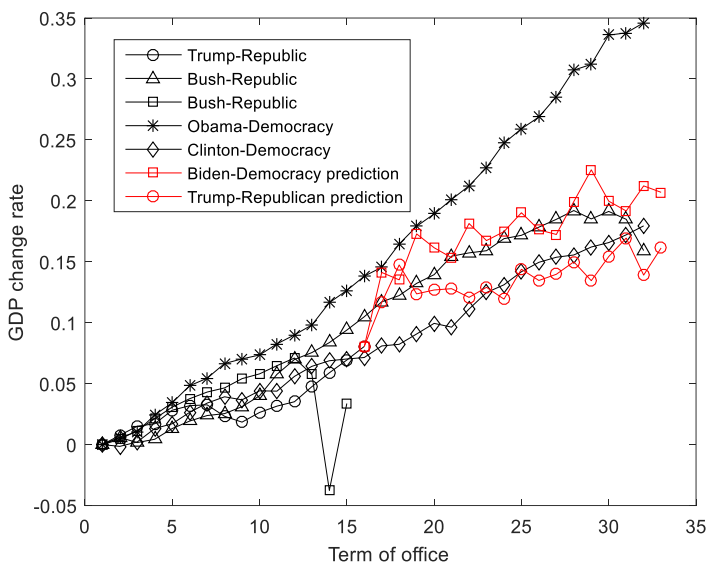

Figure 8 Changes in US GDP under different US presidents

The broadest indicator of economic activity is GDP, which measures the value of goods and services produced by the country. After adjusting for inflation, it usually increases by $2 \%$ to $3 \%$ a year. Trump has been in this range for the first three years, but it will fall sharply in 2020.We have a full data yet, but the second quarter was the worst since 1947.Third quarter data released on Thursday showed a partial recovery. As can be seen from the forecast in the figure, if Biden is elected, it will increase GDP faster to a certain extent.[7]

The infectious disease model is as follows:

$$
\begin{gathered}
\frac{d S}{d t}=-\beta \frac{S I}{N} \\
\frac{d I}{d t}=\beta \frac{S I}{N}-\gamma I \\
\frac{d R}{d t}=\gamma I
\end{gathered}
$$

Among them, $\mathrm{S}$ represents the susceptible population, I represents the infected population, and $\mathrm{R}$ represents the removed population. The above model is the mechanism process of the spread of infectious diseases, but in practice, there are actual population statistics and some parameters in the model are unknown. Therefore, optimization algorithms are needed to identify the parameters. The optimization function is:

$$
\min \sum_{t \in T}\left(e^{(\beta-\gamma) t}-\hat{I}(t)\right)^{2}
$$

The following is the epidemic situation after Biden's election based on the data collected in this article: 


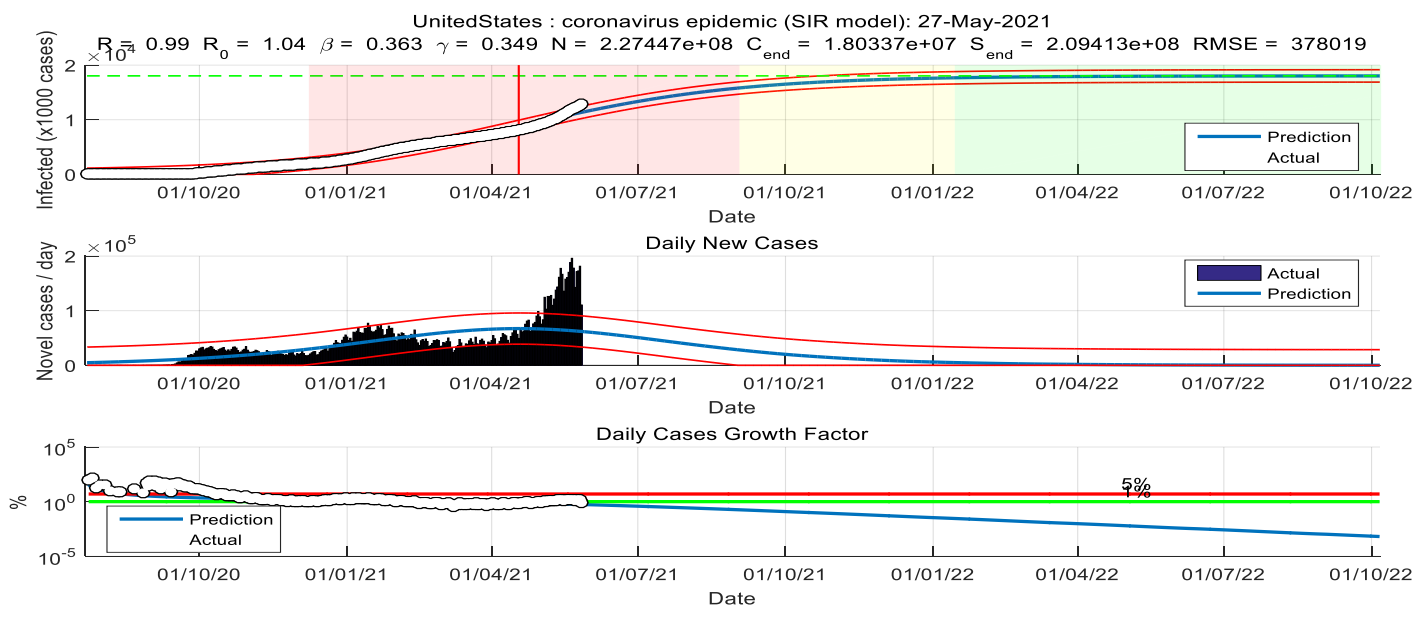

Figure 9 The development of the U.S. epidemic after Biden was elected

As can be seen from the above figure, when Biden is elected, the U.S. epidemic will stabilize and gradually disappear in 21 years; but when trump is elected, it will

UnitedStates : coronavirus epidemic (SIR model): 27-May-2021
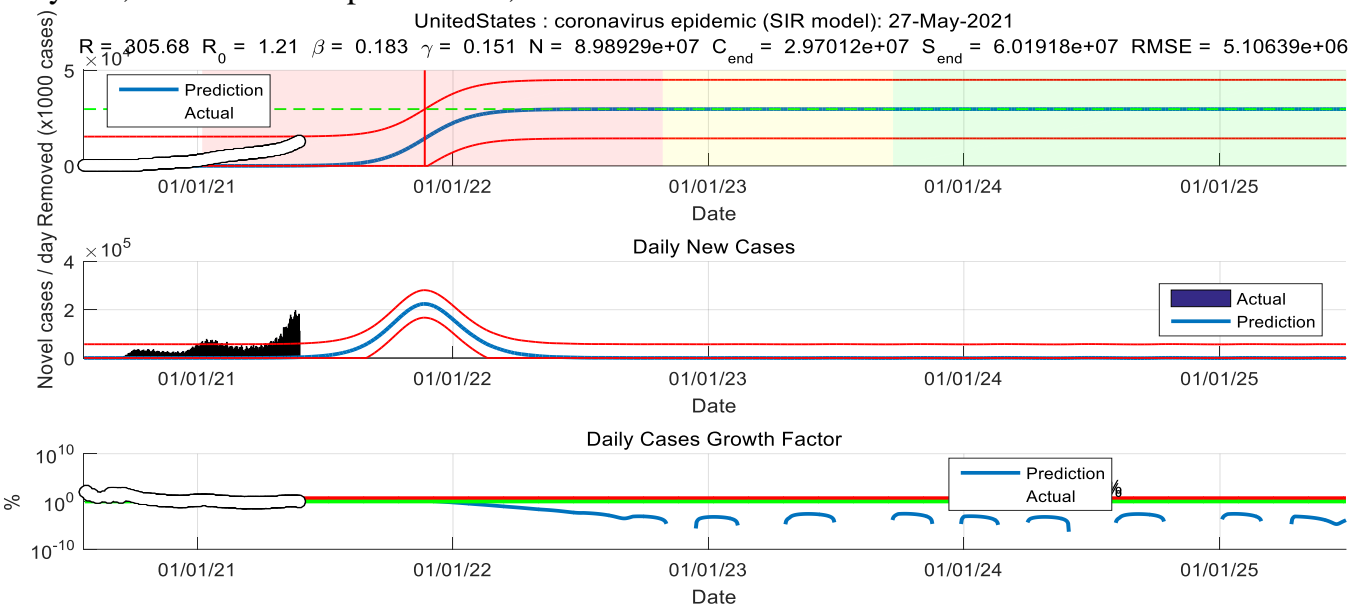

Figure 10 The development of the US epidemic after Trump was elected

To sum up, if Biden is elected, it will promote the U.S. economy to a greater extent. It will reduce the debt and unemployment rate, while trump will increase the debt and unemployment rate; at the same time, although both of them have a positive impact on GDP in the results, Biden will have a better impact; it will also do better in the fight against the epidemic.

\subsection{Analysis of the impact of US election results on China}

To analyze the impact of the U.S. election results on China, this paper first considers the impact of the U.S. Democratic Party and Republican Party on China economy, and then takes into account the foreign trade policy positions of trump and Biden, establishes the trade gravity model and grey prediction model to predict and analyze China inflation, trade, foreign investment, etc., and concludes that the U.S. election results have an impact on China economy .The concrete influence of economy.

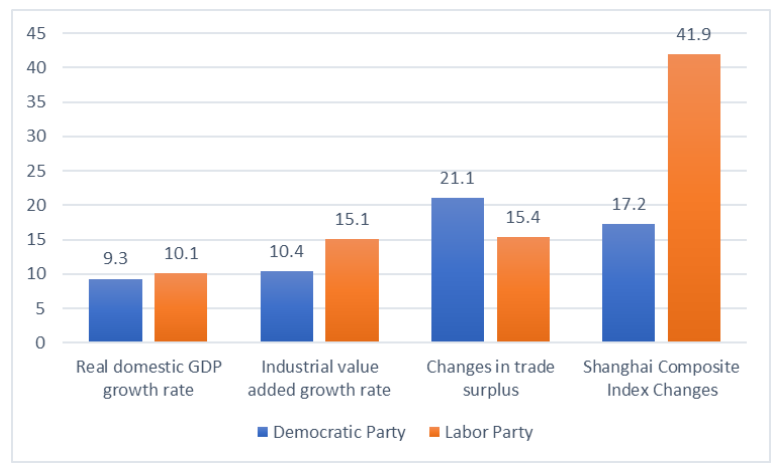

Figure 11 Comparison of the average values of some economic indicators in China

From the figure above, we can see that the influence of the Republican Party and the Democratic Party on China is very different during their ruling period. Therefore, this paper analyzes the hypothesis in the 
previous question. Firstly, the gravity model of trade is established as follows

$$
\begin{gathered}
\ln X_{t}=a_{0}+a_{1} \ln G D P C_{t}+a_{2} \ln G D P A_{t}+a_{3} \ln S P S_{t}+a_{4} \ln T B T_{t}+a_{5} \ln A C_{t} \\
+a_{6} \ln S P S(-1)_{t}+a_{7} \ln T B T(-1)_{t}+a_{8} \ln X(-1)_{t}+a_{9} \ln E X(-1)_{t} \\
+a_{10} \ln T T_{t}+\varepsilon
\end{gathered}
$$

In addition, on this basis, this paper establishes a grey prediction model.

First record the annual average as:

$$
x^{(0)}=\left(x^{(0)}(1), x^{(0)}(2), \cdots, x^{(0)}(n)\right)
$$

Accumulate them in turn to get:

$x^{(1)}(1)=x^{(0)}(1), x^{(1)}(i)=\sum_{k=1}^{i} x^{(0)}(k)(i=2,3, \cdots, n$

note:

$$
x^{(1)}=\left(x^{(1)}(1), x^{(1)}(2), \cdots, x^{(1)}(n)\right)
$$

Take the weighted mean:

$$
\begin{gathered}
z^{(1)}(k)=\alpha x^{(1)}(k)+(1-\alpha) x^{(1)}(k-1)(k \\
=2,3, \cdots, n)
\end{gathered}
$$

note:

$$
z^{(1)}=\left(z^{(1)}(2), z^{(1)}(3), \cdots, z^{(1)}(n)\right)
$$

The differential equation model of GM is:

Its matrix form is:

$$
\frac{d x^{(1)}}{d t}+a x^{(1)}=b
$$

$$
Y=B(a, b)^{T}
$$

The final estimated solution is:

$$
\begin{aligned}
& \hat{x}^{(0)}(k+1)=\hat{x}^{(1)}(k+1)-\hat{x}^{(1)}(k) \\
& =\left(x^{(0)}(1)-\frac{b}{a}\right)\left(e^{-a k}-e^{-a(k-1)}\right)
\end{aligned}
$$

then:

$$
u_{i}=\sum_{i=1}^{m} \sum_{j=1}^{n} a_{i j} / \sum_{i=1}^{m} \sum_{j=1}^{n} a_{i j},(i=1,2, \cdots, m)
$$

It can be concluded that the forecast results of each indicator are as follows:

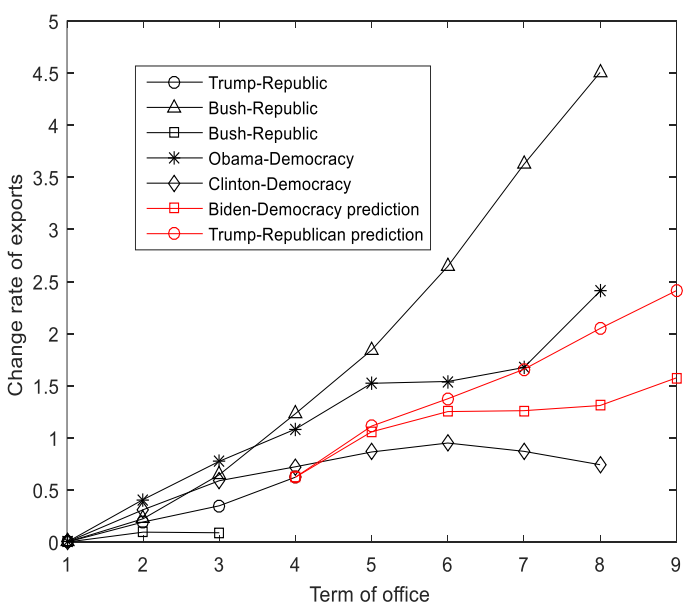

Figure 12 China's export changes in different presidential periods
As can be seen from the above figure, China's exports have basically shown an upward trend during each presidential period. From the results, if Trump is elected, it will have a better impact on China's exports than Biden

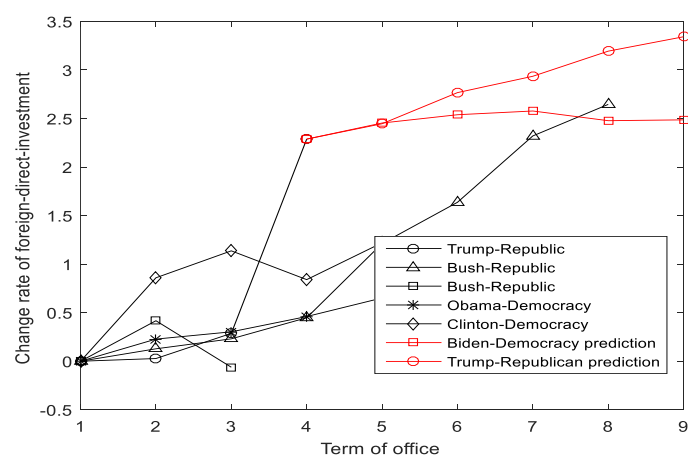

Figure13 China's foreign investment changes in different presidential periods

As can be seen from the above figure, China's foreign investment has basically shown an upward trend during each presidential period. From the result, if Trump is elected, it will have a better impact on China's foreign investment than Biden.

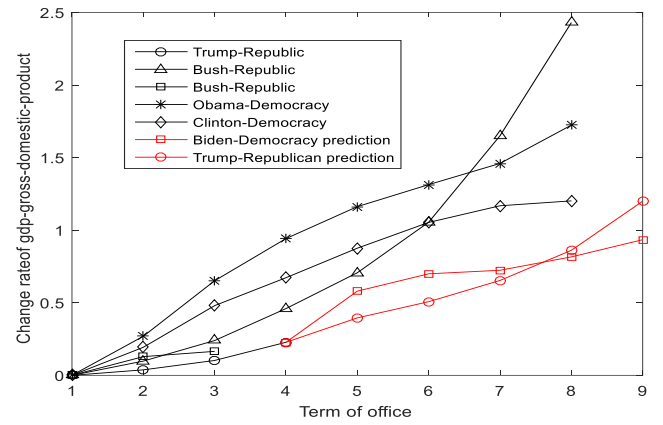

Figure 14 China's GGDP changes in different presidential periods

As can be seen from the above figure, China's GGDP has basically shown an upward trend in each presidential period. From the results, it can be seen that the election of Trump and the election of Biden have almost the same impact on China's development. 


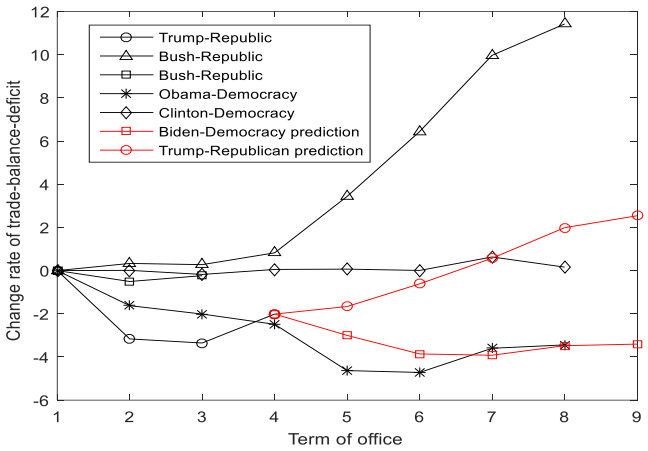

Figure 15 China's trade balance changes in different presidential periods

As can be seen from the above figure, China's trade balance has basically been stable during each presidential period. From the result, if Trump is elected, it will have a better impact on China's trade balance than Biden.

\subsection{Reasonable suggestions for China based on the results of the US election}

According to the above results, this paper analyzes and proposes relevant suggestions from three dimensions of China domestic development, China and the United States, and China and the world . Finally, the paper puts forward some reasonable suggestions, such as mobilizing domestic dual circulation, alerting Sino US relations and integrating into the world economy.

In Biden campaign platform, he specifically put forward the harm of "trade war" to American enterprises and consumers. After taking office, Biden is more likely to end the trade war with China . But at the same time, based on the policy of Obama period and the line of multilateralism, Biden will lead the United States back to the TPP and establish more trade and political alliances excluding China, so as to unite with allies to "encircle" China.

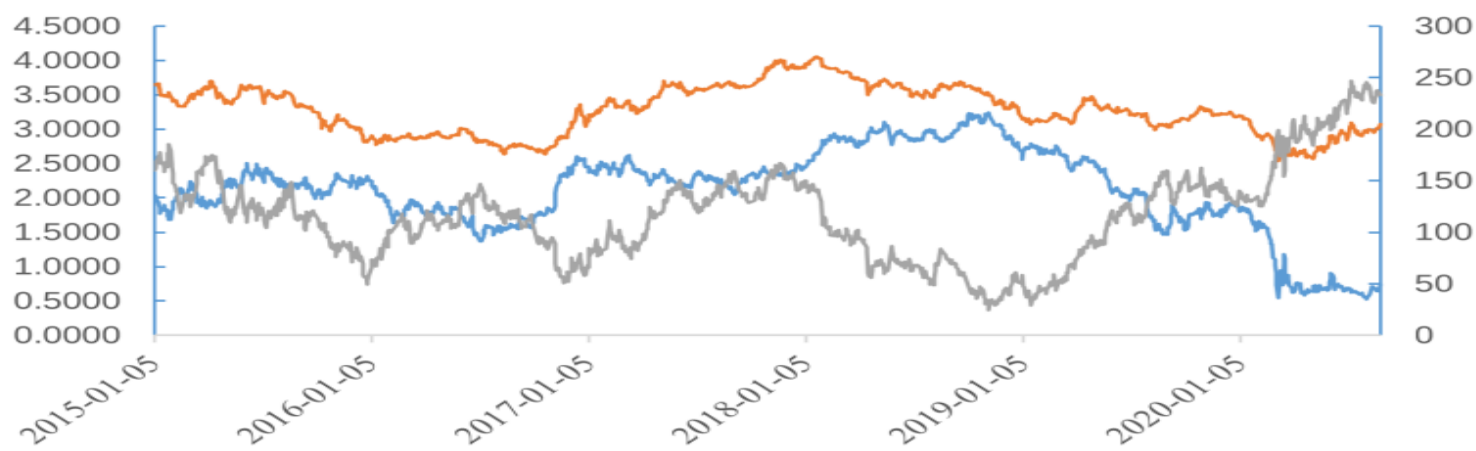

Figure 16 China U.S. bond yields

As Biden is elected president of the United States, Sino US relations may be greatly improved on the basis of the trump administration. Biden attitude towards China is the coexistence of competition and interests between
China and the United States . Therefore, China can ease the Sino US relations a little bit. We can take advantage of this period to mobilize the domestic dual cycle and develop the domestic market.[9]

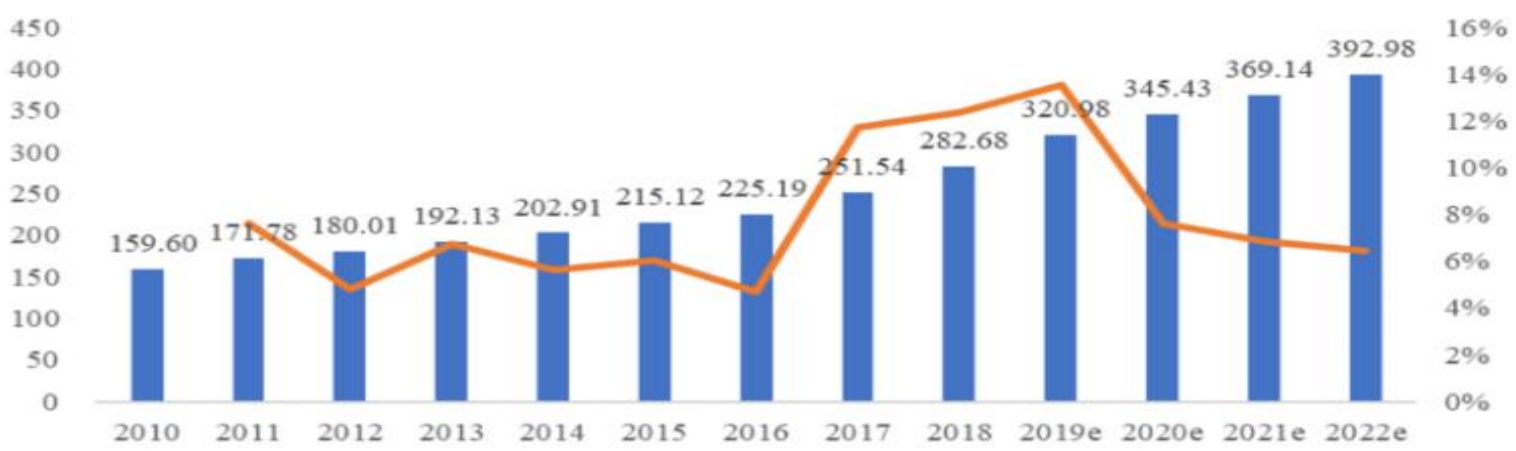

Figure 17 China-US trade surplus

But on the other hand, the United States will cooperate with China in some aspects, such as climate, North Korea nuclear issue and other issues of common interests. Unlike Trump unilateralism, Biden attaches more importance to the establishment of an international framework. Biden visited China three times in 1979, 2001 and 2011.Biden believes that the US policy towards China should be to work with it and integrate China into the international order. He also stressed the need to promote China adherence to international legal and political norms, as well as to consolidate the existing alliance, in order to prevent China from infringing upon the fundamental interests of the United States and its allies.

He opposed to regarding China as the enemy and not 
China as an ally. Instead, he recognized that China and the United States have both competition and common interests. In this regard, China can also be vigilant to cooperate with the United States, but it can never ignore the risks.

States have both competition and common interests. In this regard, China can also cooperate with the United States vigilantly, but it cannot ignore the risks.

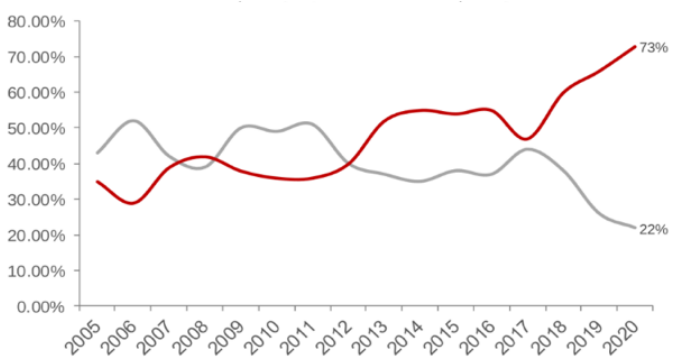

Figure 18 U.S. attitude towards China
With the increasing uncertainty of Sino US relations, even multinational enterprises in China who benefit most from Sino US economic and trade relations are becoming more cautious. As of June this year, the number of foreign-funded Industrial Enterprises above designated size was 43643, 985 less than that at the beginning of 2020 .

According to a survey of 25 large American companies conducted by the American Chamber of Commerce in China in March, only $44 \%$ said that China and the US economy could not be decoupled, significantly lower than $66 \%$ in October last year. However, from the survey of the attitude of the United States to China, more and more American people advocate being tough on China. Therefore, if China wants to further develop, it must enter the world.

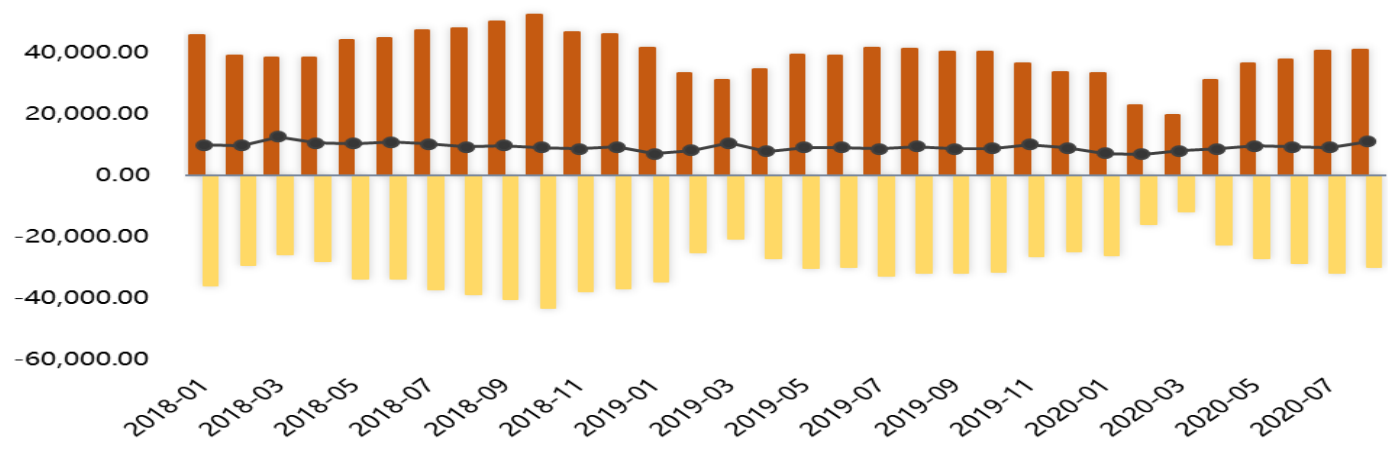

Figure 19 Scale and growth rate of a global market

In terms of science and technology, Biden believes that the United States should increase its investment in artificial intelligence, quantum computing and $5 \mathrm{~g}$ communications in order to cope with China increasing economic and political influence in these fields. Judging from the current situation, we can judge that Biden will not take the unreasonable intervention measures of trump administration in the field of science and technology. Biden will pay more attention to the image of the United States.

We are very optimistic that Huawei chip supply will be released during the Biden administration term of office. We strongly recommend companies that lay out Huawei industrial chain in advance. This may be the best "Biden deal", and the market has hardly expected this point at present. Therefore, this position is an opportunity for China to embrace the world market and gradually reduce its dependence on the United States.

\section{CONCLUSION}

In view of the first question, analyzing the impact of the election results on the United States, this paper first analyzes the economic conditions of the presidents of the United States during their political periods. It is found that the economic conditions of the Democratic Party and the Republican Party are very different during the ruling period. Therefore, this paper assumes that the influence of the president on the United States is largely determined by the political party to which he belongs . Furthermore, this paper analyzes the debt, GDP, employment and unemployment rate of different election results in time series, and concludes the specific impact of different election results on the economy . In addition, considering the different attitudes of trump and Biden on the new coronation epidemic, this paper also established a SIR model based on biology to simulate the epidemic development in the United States under different election results.

In view of the second question, analyzing the impact of the U.S. election results on China, this paper first considers the impact of the US Democratic Party and Republican Party on China economy, and then takes into account the foreign trade policy positions of trump and Biden, establishes the trade gravity model and grey prediction model to predict and analyze China inflation, trade, foreign investment, etc., and finally obtains the US election conclusion :The specific impact of the results on China economy. 
In view of the third question, based on the above results, this paper makes relevant analysis and suggestions from three dimensions of China domestic development, China and the United States, and China and the world. Finally, the paper puts forward some reasonable suggestions, such as mobilizing domestic dual circulation, alerting Sino US relations and integrating into the world economy.

\section{REFERENCES}

[1] Ma Xiaoyun. The construction of the Silk Road Economic Belt in Kazakhstan under the background of the Sino-US trade conflict[J]. Journal of Hubei University of Economics (Humanities and Social Sciences Edition), 2020, 17(12): 16-18.

[2] Zhao Changyu, Hu Ping. Application of LS-SVMbased time series prediction method in control system $[\mathrm{J}]$. Science and Technology and Innovation, 2020(22): 10-11+15.

[3] Hu Shengyuan, Pang Yong, Meng Shili, Yue Cairong. Time series Landsat 8 OLI data forest annual disturbance detection $[\mathrm{J}]$. Forestry Science Research, 2020, 33(06): 65-72.

[4] Julien Yves,Sobrino José A.. Introducing the Time Series Change Visualization and Interpretation (TSCVI) method for the interpretation of global NDVI changes[J]. International Journal of Applied Earth Observations and Geoinformation,2021,96.

[5] Chen Tingting. Measurement of the development potential of China's cross-border e-commerce in ASEAN countries under the background of the "Belt and Road Initiative"_—_Based on the empirical study of the two-stage trade gravity model[J]. Business Economics Research, 2020(22): 80-83.

[6] Liao Wenlong, Dong Xinkai, Weng Ming. Research on the construction of a new order of China-ASEAN intellectual property governance under the background of Sino-US trade frictions $[\mathrm{J}]$. Reform and Strategy, 2020, 36(11): 108-116.

[7] Liao Wenlong, Dong Xinkai, Weng Ming. Research on the construction of a new order of China-ASEAN intellectual property governance under the background of Sino-US trade frictions $[\mathrm{J}]$. Reform and Strategy, 2020, 36(11): 108-116.

[8] Lin Jiujiang. A comparative study of the changes in the economic scale of China and the United States under the epidemic $[\mathrm{J}]$. International Finance, 2020(11): 41-44.

[9] Xu Yongmei. An Empirical Analysis of the Factors Influencing China's Tea Export to the United States under the Background of Sino-US Trade Frictions[J]. China Tea, 2020, 42(11): 21-27. 